\title{
ECONOMICS AS IF SCIENCE MATTERED: THE BIOONE BUSINESS MODEL AND THE TRANSFORMATION OF SCHOLARLY PUBLISHING
}

\author{
RICHARD C. FYFFE \\ Assistant Dean of Libraries for Scholarly Communication \\ The University of Kansas \\ 502 Watson Library \\ 1425 Jayhawk Boulevard \\ Lawrence, KS 66045 \\ Telephone: 785.864 .4611 \\ Fax: 785.864.5311 \\ Internet: rfyffe@ku.edu \\ DAVID E. SHULENBURGER \\ Executive Vice Chancellor and Provost \\ The University of Kansas \\ 1450 Jayhawk Boulevard \\ Suite 250 Strong Hall \\ Lawrence, KS 66045-7535
}


Abstract: The BioOne database of scholarly journals in the biological and ecological sciences was established in the belief that broad and enduring access to scholarly literature is essential not just to the health of the scientific enterprise but also to the health of the wider society in which science is practiced. The prevailing model of profit-based journal publishing -- in which high prices are impeding access -- is harming the interests of the very scientists who provide its life-blood. The BioOne business model seeks to meet the interlocking goals of providing broad and enduring access, supporting the publishing enterprise of scholarly societies, and assuring that BioOne will keep pace with changes in technology and scientific communication.

Keywords: scholarly communication, electronic publishing, scholarly societies, library budgets, BioOne, public good economics 
Economists define a "public good" as one that cannot practically be withheld from all users whether they pay or not (non-excludability), or as one whose use by one person does not preclude use by others (rival consumption). A classic example of a public good is street lighting: once it is provided for some it is available for all, but use by a few does not exhaust the supply for others. The challenge of providing public goods is in developing viable business models that ensure a revenue stream that is not dependent on excludability, models that guarantee revenue even when the resource is available to consumers without direct payment.

The prevailing model of journal publishing uses subscription as a means of exclusion that generates revenue: subscribers have easier access to the content of the journal than do non-subscribers and are motivated by that convenience to maintain the subscription. This model is well suited to the characteristics of print-based publishing, in which the publisher must expend resources in disseminating new content to each individual customer. The model holds for both individual subscriptions and library subscriptions; publishers tend to charge higher prices for institutional subscriptions than for individual subscriptions in view of the larger community that a single subscription may serve, but it is still the convenience of a geographically proximate community that provides the primary motivation for maintaining the subscription. Over the past two decades, however, the prices of scientific journals -- particularly those published by forprofit publishers -- have risen beyond levels affordable by individual or institutional customers, and subscription-based access to research journals in academic institutions has sharply declined $[1,2]$. As a result, the very scientists on whom journals depend for 
publishable manuscripts have lost the convenience of subscription-based access to much of the current literature of their fields. Moreover, this is happening at a time when research activity is expanding as never before, with correspondingly greater need for publication venues. The BioOne database was established in the belief that broad and enduring access to scholarly literature is essential not just to the health of the scientific enterprise but also to the health of the wider society in which science is practiced. In other words, scientific literature should be priced as a public good.

The BioOne project is a collaboration among scholarly societies, universities and university libraries, and a specialist in scholarly journal production. From the beginning of the project, scholarly societies have been viewed as a link in the chain of scholarly communication whose vitality must be sustained [3]. Scholarly societies provide a forum for discussion and collaboration among members with common specialist interests, and sponsor peer-review and publication of research papers in that specialization. Moreover, the costs of journals published by scholarly societies are typically lower than those of journals published commercially (granting significant variation within both groups) as indicated by the normalized pricing studies conducted at the University of Wisconsin [4], Cornell [5], and the University of Washington [6], among others.

Electronic publishing is an important tool for improving the timeliness and extending the availability of this growing body of scholarly literature. However, the short-term costs of moving from print to electronic publishing are greater than many small societies can afford: the average subscription price for the print version of a BioOne journal is under $\$ 200$, a level that is typically too low to generate the capital reserve required to make the transition. One of the advantages held by profit-generating 
businesses is their ability invest capital in new technology; private investors can be rewarded for taking the financial risk associated with this investment. BioOne was founded to provide participating journals an alternative to affiliation with commercial publishers, and to foster the continuing financial health of the small societies. BioOne therefore represents an alternative capitalization model, one in which the scholarly community, including subscribing libraries and participating societies, shares the risk of investment to create the dividend of extended access [7].

In this paper, we describe how the BioOne business model seeks to meet the interlocking goals of providing broad and enduring access to a segment of the scientific literature, supporting the publishing enterprise of scholarly societies, and assuring that BioOne will keep pace with changes in technology and scientific communication. We stress three aspects of this model: structural decisions intended to help keep overhead and administrative costs low, a revenue-sharing arrangement with participating societies, and a capital fund that will support BioOne's technological evolution.

\section{WHAT IS BIOONE? SCHOLARLY COMMUNICATION AS A COLLABORATIVE ENTERPRISE}

BioOne is an aggregated database of forty-eight journals (as of May 2002) in whole-organism biology and ecological and environmental sciences. Thirty-nine scholarly societies are represented. The journal content is tagged in SGML to facilitate smooth migration to future technological platforms, and articles are reference-linked with each other to create a coherent and unified information resource. The initiative to create 
BioOne was announced in June of 1999, and the BioOne database was launched, on schedule, in April of 2001.

BioOne was created by five organizations that represent the key aspects of the scholarly communications process: the American Institute of Biological Societies (AIBS); the Greater Western Library Alliance (GWLA, formerly the Big Twelve Plus Libraries Consortium); the University of Kansas; the Scholarly Publishing and Academic Library Coalition (SPARC); and Allen Press, a commercial printer that specializes in scholarly and scientific journals. Each of the BioOne founding collaborators has experience that benefits this undertaking, and they are united in the conviction that highimpact, low-cost alternatives to commercially published research can play a continuing and expanding role in science $[8,9]$.

AIBS is a federation of scientific societies that facilitates the exchange and dissemination of research among its members and with the public at large, and serves about 246,000 biologists worldwide. The eighty-six AIBS societies represent the major biology groups outside the molecular-biology and biochemistry-research communities. The research foci of AIBS societies are in the general areas of ecology; environmental sciences; and macro-level, basic biological studies: systematics, botany, mammalogy, plant science, conservation biology, toxicology, agronomy, ornithology, limnology and taxonomy [10]. AIBS advocates for the interests of the member societies that choose to participate in BioOne.

GWLA represents thirty major research libraries with common objectives related to scholarly communications. With strong support from the provosts of the member institutions, GWLA has fostered discussion between libraries, faculty, and 
administrations of its member campuses on the role of universities in shaping the future of scholarly publishing [11]. The University of Kansas is a major comprehensive research and teaching university committed to research as a means of mutually reinforcing the scholarly inquiry underlying and informing the educational experience [12]. It collaborates with Allen Press in BioOne's technology development, hosts the BioOne database, and provides expertise in the development of the publisher and subscriber licenses. SPARC is a coalition of libraries that promotes and facilitates expanded competition in the scientific journals market. Charter subscriptions from SPARC members helped to capitalize BioOne's start-up costs. SPARC also contributes the product development and market experience of its staff [13]. Finally, Allen Press is a leading provider of publishing production services to scholarly societies that self-publish their journals [14]. Allen Press developed the database design and creates the SGML mark-up for most of the content delivered by BioOne.

BioOne employs a staff of one and a half (a full-time president and a part-time assistant). One of BioOne's principles is that the corporation's business practice must be financially sound if it is to fulfill its mission. A guarantee of the database's long-term availability must be founded on careful examination of revenue streams and accurate projections of market interest. BioOne therefore employs professional contractors for financial services and for marketing and subscription services (Amigos Library Services for North American sales and OCLC for international sales).

BioOne's governance structure also reflects the collaborative nature of the scholarly communication process. A volunteer Board of Directors includes representatives from the five founding organizations. The Board is supported by a 
Working Group of staff members from these organizations along with BioOne's financial and marketing consultants who meet by teleconference once a month to draft policy and review operational and subscription issues. Through the Working Group, Board decisions are informed by the business plan.

The Board is also supported by three advisory groups of stakeholders. A Publisher Advisory Group of representatives from the participating scholarly societies provides advice on identifying and recruiting appropriate content for the database and recommending appropriate linking arrangements between BioOne and other databases and journals. A Technical Advisory Group consults on such issues as system architecture, digital archiving, and discovery and retrieval tools. Finally, a Library Advisory Group provides advice and feedback on pricing and price increases, licenses, user interfaces, and priorities for developing new content within the database [15]. Membership in all three groups includes nationally respected experts in their respective specializations.

\section{PRICING FOR LONG-TERM ACCESS: WHAT MAKES BIOONE DIFFERENT?}

The last decade has seen a remarkable number of experiments in alternative business models for scholarly publishing, and just as many pricing models; one writer on this topic has identified over fifty [16]. Three elements help distinguish BioOne from many of the other business models for scholarly publishing: structural decisions intended to help keep overhead and administrative costs low, a revenue-sharing arrangement with participating societies, and a commitment to generating funds to support technological evolution. In all three cases, BioOne demonstrates its dual commitments to maintaining 
the broad accessibility and long-term availability of the literature it disseminates and to the health of the scholarly societies whose members create, review, and promote that literature.

For academic institutions, BioOne is priced according to a traditional FTE model in which institutions with larger numbers of students, faculty, and staff generally pay more than smaller institutions [17]. Academic libraries fall into one of three pricing tiers, with minimum $(\$ 2,100)$ and maximum $(\$ 9,975)$ pricing levels $(2002$ subscription year). However, unlike some other publishers of scientific literature, BioOne does not assume that only large academic institutions need to have access to this information. The chairman of Elsevier, Derk Haank, recently stated that

"when I talk about the people who need it [scientific literature], I am not talking about the general public, because we are talking here about scientific information, specialist information. People who want to use this and who need it are part of an institute. You don't do it as a self-proclaimed intellectual in your garden shed. You work within a university or in a pharmaceutical company. Either in a production environment or an academic environment, that's where you operate" [18].

By contrast, BioOne believes that science is an enterprise conducted within a broader social compact and that a healthy democracy and sound public policy require ready access to scientific literature on the part of a broad spectrum of citizens. BioOne therefore offers special pricing to community colleges (\$525-\$2,100, depending on FTE), 
public libraries (a flat rate of $\$ 1,050$ ), K-12 school libraries (a flat rate of \$500), government agency libraries, and non-profit organizations like museums and foundations. Special pricing is also available to library consortia.

BioOne is priced as an aggregation. Although each component journal retains its separate identity within the database, the database is licensed only as a single aggregation. There are two reasons for this, one functional and the other economic. Journal aggregations have been criticized within the library community for forcing a subscribing library to accept titles that it doesn't want: titles that are low in quality or outside the scope of its subject interests. However, journal aggregations can also offer greater functional convenience to users in searching and retrieving relevant literature. BioOne evaluates prospective new titles carefully to assure that the database maintains high quality and strong subject coherence, thus increasing the likelihood that a subject search across the whole database will yield relevant citations from multiple journal titles and that articles in one journal will reference other articles in the database. It is important to note, however, that BioOne also recognizes that linkages must also be established between BioOne and other databases or individually published titles. BioOne maintains its own link resolution service and supports cooperative linking projects including CrossRef [19].

BioOne seeks to keep administrative costs as low as possible so that these costs do not have to be passed to the purchasers or covered in other ways. Selling the database in parts (as individual titles or smaller groups of titles) would require time-consuming and costly accounting systems to track the selections of individual customers. In addition, because of the unique nature of the BioOne collaboration, subscription to the 
BioOne database is independent of subscription to the print journals: libraries choose, title by title, whether to maintain or drop the print counterparts. This is another way in which BioOne helps to keep administrative overhead -- and therefore prices -- lower, since BioOne does not need to track the changing print base of each customer. The participating scholarly societies, for their part, are thereby left to make the transition to electronic-only publishing (if they should choose to) at their own pace and according to their own circumstances [20].

BioOne was founded with an explicit business plan that identified the costs that had to be covered, the likely market for subscriptions, and the potential for market growth over time. The estimated size of this market helped to set the price each subscriber would pay. Among the costs that had to be funded were hardware and software; database programming and preparation of the content; marketing and promotion; and administrative and professional services. Two kinds of cost, however, deserve special attention: revenue-sharing with the contributing scholarly societies and a technology reserve fund.

One of BioOne's fundamental goals is to support the publishing activities of notfor-profit scholarly societies and thereby contribute to the long-term health of this key agency of scientific research and education. One way in which this is accomplished is through BioOne's marketing and promotional activities. In addition, all participating societies share equitably in a $50 \%$ share of BioOne's net sales receipts (i.e., the payments received by BioOne from subscribers and distributors, adjusted for returns and customer and agency discounts). This amount is one-half of BioOne's "top line" before deducting any expenses for development, production, operation, or administration. To ensure 
equitable distribution of revenues, each journal's contribution to the database is determined according to the relative number of pages in the database and the number of uses (database "hits") it received in the course of a year.

BioOne completed its first year of operation on December 31, 2001. On that date, forty-three journals and related publications from thirty-five publishers were aggregated in the BioOne database, incorporating nearly 84,000 pages and 10,000 research papers. Paid access by subscribers started in April of 2001. By December nearly 400 subscribing entities had signed up representing an authorized online user base of 3.1 million scholars, students, researchers, and professionals. For the nine-month period, net subscription receipts totaled $\$ 937,355$.

Under BioOne's revenue-sharing model, half of the net income is distributed back to the participating scholarly societies. For 2001, allocations to publishers ranged from about $\$ 400$ to over $\$ 63,000$-- on average, about $\$ 11,400$ per title and $\$ 14,000$ per publisher. More than half the publishers realized a 2001 revenue share over $\$ 10,000$ [21]. For most of these societies, this represents a substantial new source of income that helps to support their primary publishing activities. Subscriptions to the BioOne database directly support the scientific enterprise; they are not diverted into share-holder dividends.

It is possible, of course, that the availability of the BioOne database will lead to a loss of print subscriptions for the participating societies. Income from the BioOne revenue-share may not entirely replace this lost income, and the impact on each participating society cannot be predicted. However, as electronic communication in the ecological sciences becomes the norm, societies may see the loss of print subscriptions 
anyway. To remain economically viable and assure their continuing relevance to their members, societies should be developing diverse streams of income and diverse member services. Similarly, to assure the broadest distribution of scholarly literature at the lowest possible cost to users, publishers should be developing additional sources of financial support beyond subscription costs. Organizational planning and development of these sorts are necessary if scholarly societies and publishers are to remain vital institutions within the broader culture.

BioOne also recognizes that the technologies of electronic publishing change rapidly, as do the needs and expectations of its users. To assure that BioOne keeps pace with technological developments, a reserve fund is part of the BioOne business model. This fund will support migration to new hardware and software platforms and introduction of new search, retrieval, and presentation features. However, planning for future technology is more than just a strategy to keep pace with competing publishers. Digital information can only be preserved through an active program of maintenance and migration; it will not be preserved "by accident." BioOne is committed to assuring the long-term availability of its scholarly content and the reserve fund is a key part of the BioOne preservation strategy.

What will happen if the BioOne business fails, however, or if the participating societies cease to publish new scholarly work? Not all eventualities can be planned for, and in a digital environment some degree of risk must be accepted by all stakeholders in the scholarly communication process. However, the University of Kansas has committed to maintain the BioOne archive in perpetuity, as part of its mission to help preserve the record of research and scholarship. 
For the subscription year beginning in April, 2002, BioOne's pricing for most subscribers rose $5 \%$. For college and university libraries paying the maximum rate, this represented an increase of $\$ 475$. Prices for smaller academic libraries and for public libraries rose between $\$ 25$ and $\$ 100$. These increases help to cover the additional costs associated with increased content. However, calculated on a per-title basis, BioOne actually dropped in price. BioOne was launched in April, 2001, with forty titles. For subscribers at the maximum rate $(\$ 9,500)$ this represented a price of $\$ 237.50$ per title. BioOne ended the calendar year with forty-three titles, for a maximum cost of $\$ 220.93$ per title. The subscription year beginning in April, 2002 (with a maximum rate of $\$ 9,975)$, started out with forty-seven titles in the database for a maximum per-title cost of $\$ 212.23$. Additional titles will be added later in the subscription year. Most large academic subscribers enjoy the consortial discount of $10 \%$. Their per-title price was thus \$213.75, \$198.83, and \$191.01 respectively.

Nevertheless, BioOne recognizes that most library budgets are not indexed to the cost of their existing subscriptions, much less to the cost of newly available resources. Most libraries must work within level or declining budgets, and subscription costs, not unit costs, are what matter. BioOne makes every effort to add content with minimal price increases, and consults closely with its customers and its Library Advisory Group before setting new prices.

\section{LOOKING TO THE FUTURE: SCHOLARLY LITERATURE AS A PUBLIC GOOD}

There is a growing movement of scientists and other scholars worldwide who believe that access to scientific literature should be free of cost to the subscriber. They 
object to the constraints imposed by subscription-based tolls on literature that they themselves have created, based on research funded by public grant agencies, that they have given freely to publishers. In a world of networked digital communication, they believe, scholarly literature can function very much like a public good. Like street lighting, use of a digital file by one reader need not exclude its use by another reader -opening it to unlimited consumption will not exhaust the "supply". Traditional subscription models guarantee a revenue stream by creating exclusions: in a print-based system, subscriptions cover the high marginal cost of creating and distributing each additional copy, and single copies cannot easily be shared among very large numbers of users or users who are geographically dispersed. In an electronic system, by contrast, the marginal costs for each additional user are much lower and the number of users is not limited by physical proximity.

Open-access movements like the Public Library of Science [23] and the Budapest Open Access Initiative [23] share BioOne's core belief that both science and society benefit most when access to scientific information is as broad as possible. Society benefits through the availability of a body of knowledge-claims that have been carefully evaluated by communities of disciplinary experts, and by sharing in the process by which priorities are set for public funding of scientific research. Science benefits when the pool of potential critics and evaluators of its methods and claims is as large as possible. Nevertheless, electronic publication is not cost-free, and the revenue stream to support electronic systems cannot be left to chance if the resource is to be reliably available over the long term. A multi-year business plan is necessary to provide that stability. 
However, the lower marginal costs in electronic publishing schemes do open the practical possibility of introducing revenue at other points than just the subscription. If costs can be covered by other means, then access can be opened to many more -- if not all -- users. As a consequence, BioOne recognizes the importance of developing ancillary revenue streams to help offset the price of subscription. This is a high priority of the BioOne Working Group in 2002.

Over the next few years, some of the fifty pricing models now at work in the marketplace will prove more successful than others. New models and variations on older models will emerge. This kind of experimentation and testing is necessary as the scholarly community makes its transition from a print-based economy to one based largely or exclusively on electronic publishing. The BioOne experiment is important because it attempts to take account of the connections between the various agents in the chain of scholarly communication: scholarly societies and their members, the scientists who create and evaluate the scientific literature; libraries and librarians, who organize access to it; technology specialists, who design and create the formatting schemes, storage systems, and search-and-retrieval mechanisms that make the information usable; and administrative, financial, and marketing professionals, who provide some long-term stability for the venture. BioOne's vision is fundamentally ecological: none of these agents can flourish without the others, and the most sustainable model is one that seeks the success of them all. 


\section{REFERENCES}

[1] "A straight-line projection suggests that the average journal title, which cost $\$ 125$ in 1986, will cost $\$ 1,158$ in 2012. Simply to maintain serials collections at present levels, the average journals budget, currently $\$ 4$ million, would have to increase to $\$ 14.28$ million by 2012 --over $\$ 3$ million more than what the budget would be if it continued at its current rate of increase." See Mary M. Case, "The Impact of Serial Costs on Library Collections," ARL Bimonthly Report 218 (October 2001), 9:

$<$ http://www.arl.org/newsltr/218/costimpact.html $>$ (accessed 28 April 2002).

[2] Cummings, Anthony M., Marcia L. Witte, William G. Bowen, Laura O. Lazarus, and Richard H. Ekman. University Libraries and Scholarly Communication: A Study Prepared for The Andrew W. Mellon Foundation. Washington: Association of Research Libraries, 1992.

[3] Guedon, Jean-Claude. "In Oldenburg's Long Shadow: Librarians, Research Scientists, Publishers, and the Control of Scientific Publishing," Proceedings of the 138th Annual Meeting of the Association of Research Libraries (2001): http://www.arl.org/arl/proceedings/138/index.html (accessed 27 April 2002).

[4] Soete, George. "Measuring the Cost-Effectiveness of Journals: Ten Years After Barschall." http://www.library.wisc.edu/projects/glsdo/cost.html (accessed 28 April 2002). 
[5] Faculty Taskforce, College of Agriculture and Life Sciences, Cornell University.

"Journal Price Study: Core Agricultural and Biological Journals."

http://jan.mannlib.cornell.edu/jps/jps.htm (accessed 28 April 2002).

[6] "Per Page Costs of Atmospheric Sciences Journal Titles at the University of Washington," http://www.lib.washington.edu/subject/atmosphericsci/scholcom/ (accessed 28 April 2002).

[7] On the economics of scholarly journal production and distribution, see Tenopir, Carol, and Donald W. King, Towards Electronic Journals: Realities for Scientists, Librarians, and Publishers. Washington, D.C.: Special Libraries Association, 2000.

[8] Alexander, Adrian, and Marilu Goodyear. "The Development Of BioOne: Changing the Role of Research Libraries in Scholarly Communication," The Journal of Electronic Publishing, 5:3 (March, 2000): http://www.press.umich.edu/jep/05-03/alexander.html (accessed 23 April 2002).

[9] Johnson, Richard K. "A Question of Access: SPARC, BioOne and Society-driven Electronic Publishing," D-Lib Magazine 6:5 (May 2000): http://www.dlib.org/dlib/may00/johnson/05johnson.html (accessed 23 April 2002).

[10] The American Institute of Biological Sciences: http://www.aibs.org/ 
[11] The Greater Western Library Alliance: http://www.gwla.org/

[12] The University of Kansas: http://www.ku.edu/

[13] SPARC: http://www.arl.org/sparc/

[14] Allen Press: http://www.allenpress.com/

[15] "Principal Contacts for BioOne," http://www.bioone.org/bioone/?request=get$\underline{\text { static \&name }=\text { get-contacts }}($ accessed 18 May 2002)

[16] Rhind-Tutt, Stephen. "What a Tangled Web We Weave," Against the Grain 10: 1 (February 1998), 24. His table of pricing models is reproduced at http://www.cas.usf.edu/lis/lis6511/week4/pricing.htm (accessed 27April 2002).

[17] "BioOne Price List," http://www.bioone.org/images/price-list.pdf (accessed 23 April 2002).

[18] Kaser, Dick."Ghost in a Bottle: Elsevier Science Chairman Derk Haank Responds to the Public Library of Science Initiative," Information Today 19:2 (February 2002): http://www.infotoday.com/it/feb02/kaser.htm (accessed 25 April 2002).

[19] CrossRef: http://www.crossref.org/home.htm (accessed 26 April 2002). 
[20] Publishers are authorized to use the SGML-tagged files created by BioOne in independ publications one year after they appear in the BioOne database. See the BioOne Electronic Licensing Agreement, http://www.bioone.org/images/lic-agree.pdf (accessed 12 May 2002).

[21] "Benefits for Participating Publishers," http://www.bioone.org/images/pub-benefits.pdf (accessed 23 April 2002).

[22] Public Library of Science: http://www.publiclibraryofscience.org (accessed 25 April 2002).

[23] Budapest Open Access Initiative: http://www.soros.org/openaccess/ (accessed 25 April 2002). 